\title{
Pengaruh Range of Motion (ROM) Aktif Terhadap Fleksibilitas Sendi Lutut Pada Lanjut Usia
}

\author{
Indrayana Tavip ${ }^{1 *}$, Warijan ${ }^{2}$, Siswanto Joni ${ }^{3}$ \\ 1,2,3 Prodi D-III Keperawatan Blora, Poltekkes Kemenkes Semarang, Indonesia
}

*Corresponding author : Tavip Indrayana

Email: tavip.indra@gmail.com

Received: March 11, 2020; Accepted: March 20, 2020, Published : March 31, 2020

\begin{abstract}
Background : Joint flexibility decreases in old age due to a degenerative process resulting in changes in joints, connective tissue and cartilage in the elderly. Decreasing flexibility is also due to reduced elasticity of muscle fibers, where connective tissue in muscle fibers increases (Mariyam, 2008).

Objective : The aim of this study was to analyze the effect of active exercise (ROM) on the lower extremities on increasing the flexibility of the knee joint in the elderly

Methods : This study using a quasi-experimental approach with One group pre-test and post-test design. The sampling technique uses the Slovin method of 42 people, obtained a sample of 25 elderly. Exercise is done twice a day for 8 days. Measurements were made on day 1, day 4 and day 8 of the study using a Goniometer measuring instrument..

Result : The results of measurement I average of the right knee joint $117.52 \mathrm{o}$, measurement II $=122.24$, measurement III $=126,360$. From the analysis with Paired simple t-Test between the measurements I and II, it was found that the different test measurements I and II t count value was equal to -1.908 with 0.068 . Because sig $>0.05$, it can be concluded that Ho is accepted, meaning that the average angle of ROM before and after training is the same (not different). In the different test measurements II and III the value of $t$ count is equal to -2.152 with sig 0.042 .

Conclusion : Because sig $<0.05$, it can be concluded that Ho is rejected, meaning that there is a difference in ROM angle after training between days 4 to 8 with the first day to day 4 . Thus it can be stated that active ROM exercises affect the angle of ROM of the knee joint elderly after exercise ROM between day 4 to day 8 .
\end{abstract}

Keywords: active ROM exercise, flexibility of knee joint, elderly.

\section{Pendahuluan}

Data Badan Pusat Statistik menunjukkan bahwa penduduk lanjut usia di Indonesia pada tahun 2000 mendekati 14.5 juta jiwa, tahun 2010 meningkat mendekati 24 juta jiwa dan dioerkirakan pada tahun tahun 2020 diprediksikan mencapai 29 juta jiwa. Lanjut usia adalah bagian dari proses tumbuh kembang. Manusia tidak secara tiba-tiba menjadi tua, tetapi berkembang dari bayi, anak-anak, dewasa dan akhirnya menjadi tua. Hal ini normal, dengan perubahan fisik dan tingkah laku yang dapat diramalkan yang terjadi pada semua orang pada saat mereka mencapai usia tahap perkembangan kronologis tertentu. Di masa ini seseorang mengalami kemunduran fisik, mental dan sosial secara bertahap (Azizah, 2011).

Fleksibilitas atau kelenturan sendi merupakan suatu gerak maksimal yang dapat dilakukan oleh persendian yang meliputi hubungan antara bentuk persendian, otot, tendon dan ligamen sekeliling persendian (Nieman, 2004). Proses menua menyebabkan penurunan produksi cairan sinovial pada persendian dan tonus otot, kartilago sendi menjadi lebih tipis dan ligamentum menjadilebih kaku serta terjadi penurunan kelenturan (fleksibilitas), sehingga mengurangi gerakan persendian. Kekakuan dapat disebabkan oleh adanya kalsifikasi pada lansia yang akan menurunkan fleksibilitas sendi (Mariyam, 2008). Sendi lutut mempunyai struktur ligamentum yang kuat karena berfungsi sebagai penopang tubuh, hal ini juga akan mempengaruhi kemungkinan terjadinya kekakuan pada sendi lutut (Tortora \& Grabowski, 2003).

Latihan rentang gerak atau Range ofMotion (ROM) adalah kemampuan maksimalseseorang dalam melakukan gerakan. Merupakan ruang gerak atau batas-batas gerakan dari kontraksi otot dalam melakukan gerakan, apakah otot memendek secara 
penuh atau tidak, atau memanjang secara penuh atau tidak. ROM dapat mencegah terjadinya kontraktur, atropi otot, meningkatkan peredaran darah ke esktremitas, mengurangi kelumpuhan vaskular, dan memberikan kenyamanan pada klien. Perawat harusmempersiapkan, membantu, dan mengajarkan klien untuk latihan rentang gerak yang meliputi semua sendi (Lukman \& Ningsih, 2012).

Latihan ROM merupakan latihan yang menggerakkan persendian seoptimal dan seluas mungkin sesuai kemampuan seseorang yang tidak menimbulkan rasa nyeri pada sendi yang digerakkan. Adanya pergerakan pada persendian akan menyebabkan terjadinya peningkatan aliran darah ke dalam kapsula sendi (Astrand dan Rodahl, 2003). Ketika sendi digerakkan, permukaan kartilago antara kedua tulang akan saling bergesekan. Kartilago banyak mengandung proteoglikans yang menempel pada asam hialuronat yang bersifat hidrophilik, sehingga kartilago banyak mengandung air sebanyak 70-75\%. Adanya penekanan pada kartilago akan mendesak air keluar dari matrik kartilago ke cairan sinovial. Bila tekanan berhenti maka air yang keluar ke cairan sinovial akan ditarik kembali dengan membawa nutrisi dari cairan sinovial (Loeser, 2009; Jenkins, 2005). Sehingga dengan dilakukan latihan ROM pada klien gangguan sendi dapat menjalankan aktivitas kehidupan sehari-hari dengan lebih mandiri.

Penelitian Ulliya (2007), merupakan eksperimen dengan pre post test design.Subyek sebanyak 8 yang dilakukan latihan ROM sebanyak 5 kali dalam seminggu selama 6 minggu. Fleksibilitas sendi diukur pada sebelum, setelah 3 minggu dan setelah 6 minggu latihan ROM. Hasil penelitian menunjukkan bahwa ada peningkatan yang signifikan antara pengukuran pertama-kedua pada fleksi sendi lutut kanan dan kiri dan antara pengukuran pertama-ketiga pada fleksi sendi lutut kiri. Simpulan pada penelitian ini adalah latihan ROM selama 6 minggu dapat meningkatkan fleksibilitas sendi lutut kiri sebesar $35^{\circ}$ atau $43,75 \%$.

Hasil studi pendahuluan yang dilakukan pada tanggal 23 Desember 2017 di Panti Wreda Margo Mukti Rembang didapatkan jumlah lansia sebanyak 73 lansia. Berdasarkan hasil wawancara dan melakukan pengukuran fleksibilitas sendi terhadap 10 orang lansia dengan menggunakan goniometer merek PASS diperoleh 7 orang $(70,0 \%)$ mempunyai fleksibilitas sendi lutut masih baik yaitu rentang pergerakan sendi masih mencapai 120 derajat dan mengatakan dapat melakukan sebagian besar aktivitas keseharian meskipun kadang-kadang mengalami kelemahan fisik. Diperoleh pula 3 orang (30,0\%) mengalamipenurunan fleksibilitas sendi lutut karena rentang pergerakan sendi tidak dapat mencapai 120 derajat dan mengatakan tidak dapat melakukan sebagian besar aktivitas keseharian dan sering mengalami kelemahan fisik. Upaya yang selama ini dilakukan dengan memberikan obat nyeri tulang, balsam, koyo, pijat dan istirahat (tidur).

Lanjut usia bukanlah sekedar kondisi yang harus diterima dengan segala konsekuensinya. Mengalami degenerasi, semakin lemah, sering mengeluh sakit dan lain sebagainya. Namun dengan upaya meningkatkatkan kesehatan dan kesejahteraannya mereka bias menikmati hidup yang lebih baik. Latihan ROM salah satu solusi untuk meningkatkan kesehatan dengan menjaga kelenturan otot, kelancaran peredaran darah dan refreshing dapat membantu para lanjut usia menjadi lebih sehat.

Berdasarkan latar belakang di atas maka peneliti tertarik untuk melakukan penelitian dengan mengambil judul, "Pengaruh LatihanRange of Motion (ROM) Ekstremitas Bawah Aktif terhadap Fleksibilitas Sendi Lutut pada Lansia di Panti Wreda Margo Mukti Rembang".

Secara umum penelitian ini bertujuan untuk mengetahui pengaruh Latihan Range of Motion (ROM) Ekstremitas Bawah Aktif terhadap fleksibilitas sendi lutut pada lansia di Panti Wreda Margo Mukti Rembang.

Diharapkan hasil penelitian ini dapat digunakan sebagai bahan masukan dalam upaya membina dan mengembangkan perawat gerontik dan keluarga dalam memberikan pelayanan padalansia. Memberikan masukan kepada pengelola pendidikan keperawatan untuk lebih mengenalkan latihan ROM kepada peserta didiknya. Memberikan pengetahuan keluarga dan petugas Panti Wreda Margo Mukti Rembang tentang latihan ROM.

\section{Metode Penelitian}

Penelitian ini merupakan penelitian kuantitatif dengan desain Pra Experiment dengan metode One Group pre-post test design.

Populasi dalam penelitian ini adalah lansia yang berusia $>65$ tahun di Rumah Pelayanan Sosial Lanjut Usia (Panti Wreda) Margo Mukti Rembang. Jumlah penghuni panti 42 orang. Namun yang memenuhi criteria inklusi maupun eksklusi sebanyak 27 orang.

Dengan menggunakan rumus Slovin:

$\mathrm{n}=\mathrm{N} /(\mathrm{N} \mathrm{e})^{2}+1=27 /(27 \mathrm{x} 0,05)^{2}+1=25,29$ dibulatkan menjadi 25, dengan demikian, jumlah sampel yang dibutuhkan adalah 25 responden..

1. Kriteria Inklusi :
a. Penghuni Panti Wreda Margo Mukti Rembang yang berusia 60 th keatas.
b. Dapat bergerak secara aktif
c. Kooperatif

2. Kriteria eksklusi :

a. Menderita inflamasi /lesi muskuloskeletal

b. Menderita gangguan saraf motorik (kelumpuhan) 
Menderita penyakit yang terganggu oleh aktifitas (Kardiovaskuler/pernapasan)

\section{Hasil dan Pembahasan}

Sebagian besar dari responden mempunyai umur antara 60 - 74 tahun yaitu $76 \%$. Dan $64 \%$ adalah perempuan. Penelitiam ini bertujuan menganalisa pengaruh latihan aktif (ROM) pada ekstremitas bawah terhadap peningkatan fleksibilitas sendi lutut pada lansia dan menggunakan pendekatan quasi-eksperimen dengan One group pre-test and post-test design. Teknik sampling menggunakan total sampling yaitu sebanyak 25 lansia. Pengkuran dilakukan pada saat hari ke-1, hari ke-4 dan hari ke-8 penelitian dengan menggunakan alat ukur goniometer.

Pada uji Paired Samples Statistic menunjukkan bahwa rata-rata pengukuran pada sebelum dan sesudah latihan ROM aktif. Sebelum latihan ROM aktif rata-rata ukuran sudut ROM sendi lutut adalah $117,52^{\circ}$, sementara setelah latihan ROM aktif pengukuran II sudut ROM sendi lutut rata-rata $122,24^{\circ}$. Dan pengukuran III sudut ROM sendi lutut rata-rata $126,36^{\circ}$.

Sedangkan pada uji Paired samples Correlatian menunjukkan bahwa korelasi antara pengukuran I dan II adalah sebesar 0,626 dengan sig sebesar 0.001. Hal ini menunjukkan bahwa korelasi antara rata-rata sudut ROM pada pengukuran I (sebelum latihan) dan pengukuran II sesudah latihan ROM aktif adalah kuat dan signifikan. Sedangkan korelasi antara pengukuran II dan III sebesar 0,438 dengan sig sebesar 0.028. Hal ini menunjukkan bahwa korelasi antara rata-rata sudut ROM pada pengukuran II dan III adalah lemah dan tidak signifikan.

Hasil uji hipotesis menunjukkan bahwa pair 1 nilai t hitung adalah sebesar -1.908 degan sig 0.068 . Karena sig > 0.05 maka dapat disimpulkan bahwa Ho diterima, artinya rata-rata sudut ROM sebelum dan sesudah latihan adalah sama (tidak berbeda). Pada pair 2 nilai thitung adalah sebesar -2.152 degan sig 0.042 . Karena sig $<0.05$ maka dapat disimpulkan bahwa Ho ditolak, artinya rata-rata sudut ROM sebelum dan sesudah latihan adalah tidak sama (berbeda). dengan demikian dapat dinyatakan bahwa latihan ROM aktif mempengaruhi sudut ROM sendi lutut pada latihan hari ke 4 sampai hari ke 8.

Dalam penelitian menunjuk kan kondisi awal rentang gerak lansia pada kedua kelompok rata-rata memiliki keterbatasan rentang gerak. Hal tersebut terlihat dari rata-rata rentang gerak yang dibawah batas normal rentang gerak. Rentang gerak fleksi lutut pada kedua kelompok masih dibawah 130', Sedangkan ekstensi dalam batas normal yaitu antara $0^{\mathrm{o}-10^{\circ} \text {. }}$
Penurunan fleksibilitas pada lansia terjadi karena pada persendian, jaringan ikat dan tulang mengalami degenerasi sehingga elastisitas jaringan ikat dan tulang rawan berkurang. Perubahan elastisitas serabut otot juga mempengaruhi fleksibilitas, dimana jaringan ikat didalam serabut otot bertambah (Primana, 2006).

Hal ini juga dipengaruhi oleh adanya penyakit penyerta yang memperburuk kemampuan rentang gerak lansia. Sebagian besar lansia dalam penelitian ini memiliki penyakit penyerta seperti Remathoid Atritis dan Athritis Gout yang berhubungan dengan penurunan kemampuan rentang gerak pada lansia. Banyak keterbatasan rentang gerak akibat dari arthritis. Nyeri, bengkak sendi dan keterbatasan gerak akhirnya menimbulkan perubahan dalam ROM yang normal (Jenkins, 2005).

Data post test rentang gerak pada kelompok perlakuan setelah pemberian latihan ROM aktif menunjukkan adanya peningkatan rentang gerak. Setelah pemberian latihan ROM aktif rata-rata rentang gerak sendi berada dalam batas normal. fleksi lutut antara $120^{\circ}-135^{\circ}$ dan ekstensi antara $0^{0}$ $10^{0}$.

Menurut Jenkins (2005), penurunan ROM disebabkan oleh tidak adanya aktivitas dan latihan untuk mempertahankan kenormalan ROM, sendi dan otot dengan maksimum dan dilakukan secara teratur. Terjadi degenerasi, erosi dan kalsifikasi pada kartilago dan kapsul sendi. Sendi kehilangan fleksibilitasnya sehingga terjadi penurunan luas gerak sendi (Pudjiastuti dan Utomo, 2003).

\section{Pengaruh ROM Terhadap Peningkatan Rentang Gerak}

Berdasarkan analisa data yang terkumpul, terdapat perbedaan antara pre test dan post test rentang gerakpada kelompok perlakuan setelah dilakukan latihan Range of Motion (ROM) aktif. Ratarata rentang gerak sendi lutut pada lansia di Panti Wreda Margo Mukti Rembang sebagai kelompok perlakuan meningkat. Dari hasil tersebut, maka dapat disimpulkan bahwa ada pengaruh latihan RangeOf Motion (ROM) aktif terhadappeningkatan rentang gerak sendi pada lansia.

Hasil ini sesuai dengan penelitian Ulliya, Soempeno, dan Kushartanti (2007) tentang "Pengaruh Latihan Range Of Motion (ROM) Terhadap Fleksibilitas Sendi Lutut Pada Lansia Di Panti Wreda Wening Wardoyo Ungaran". Penelitian ini menunjukkan bahwa ada peningkatan yang signifikan antara pengukuran pertama-kedua pada fleksi lutut kanan dan kiri dan antara pengukuran pertama-ketiga pada fleksi sendi lutut kiri

Adanya pergerakan pada persendian akan menyebabkan terjadinya peningkatan aliran darah ke dalam kapsula sendi dan memberikan nutrisi yang memungkinkan tulang untuk bergerak dengan 
lancar dan tanpa rasa sakit atau ketidaknyamanan (Jenkins, 2005).

Jika terjadi penurunan gerak atau mobilitas maka aliran darah berkurang, sendi menjadi kaku dan menyakitkan, hal ini menyebabkan penurunan aktivitas dan pada akhirnya rentang gerak akan semakin mengalami penurunan dan keterbatasan gerak (Jenkins, 2005).

\section{Kesimpulan}

Rentang gerak sendi lutut pada lansia di RPSUL Panti WredaMargo Mukti Rembang sebelum dilakukan latihan ROM aktif rata-rata di bawah batas normal.

Rentang gerak sendi lutut pada lansia di Panti WredaMargo Mukti Rembang setelah dilakukan latihan ROM aktif rata-rata dalam batas normal.

Waktu yang paling efektif untuk latihan ROM aktif pada lansia dilaksanakan setiap hari mengingat banyak kondisi anatomi maupun fisiologi yang lansia yang mengalami degenerasi.

\section{Acknowledgement}

Ucapan banyak terimakasih disampaikan kepada semua pihak yang telah membantu terlaksananya kegiatan penelitian oleh tim Peneliti Prodi Keperawatan Blora Politeknik Kesehatan Kemenkes Semarang.

\section{Pustaka}

1. Astrand, P.O \&Rodahl, K. 1989. Textbook of Work Physiology. Second edition. Philadelphia: WB Saunders Co.

2. Azizah, M. L. 2011. Keperawatan lanjut usia. Jakarta : Graha Ilmu

3. Delp, M. H. \& Manning, R. T. 2003. Mayor's Physical Diagnosis: an Introduction to the Clinical Proces. Tokyo: Igaku Shomi.

4. Jenkins, L. 2005. Mazimzing Range of Motion In Older Adult. The Journal on Active Aging. January February, 50-5.

5. Lukman \& Ningsih, 2012. Asuhan Keperawatan Pada Klien Dengan. Gangguan Sistem Muskuloskeletal. Jilid 1. Jakarta : Salemba Medika

6. Loeser, R.F., Delbono, O. 2009. Aging of the muscle and joints. In:Halter JB, editor. Hazzard,s geriatric medicine and gerontology. Chicago: Mc Graw Hill.

7. Maryam, S., Ekasari, Rosidawati, Jubaididan Batubara, 2008. Mengenal Usia Lanjut dan Perawatannya. Jakarta: Salemba.

8. Nieman D.C, 2004. Kebugaran dan Kesehatan Anda alih bahasa Syahrastani, Mkes, Universitas Negeri Padang
9. Ozkaya, N dan Nordin, M, 2009. Fundamentals of biomechanics, Springer-Verlag. USA, 2nd Ed.

10. Potter \& Perry. 2006.Buku Ajar Fundamental Keperawatan:

11. Konsep, Proses, dan Praktik, Jakarta: EGC

12. Tortora, GR \& Grabowski, SH. 2003. Principles of Anatomy and Physiology. Harper Collins College Publishers. New York.

13. Uliya S, Soempeno B, Kushartani BM. \& Wara. 2007. Pengaruh Latihan Range of Motion (ROM) terhadap Fleksibilitas Sendi Lutut pada Lansia di Panti Wreda Wening Wardoyo Ungaran. Media Ners .Volume 1.Nomor: 2. Oktober 2007

14. Undang-Undang Republik Indonesia Nomor 13 Tahun 1998 Tentang Kesejahteraan Lanjut Usia 